\title{
Educação, diversidade e respeito à identidade cultural
}

\author{
Rosinalda Olaséní Corrêa da Silva Simoni 1 (D) \\ Universidade Federal do Tocantins e Pontificia Universidade Católica de Goiás
}

\section{Dossiê | Dossier | Dosier \\ DOI do artigo: 10.22481/odeere.v6i01.8522 RESUMO}

A presente proposta tem como objetivo dialogar sobre o papel social da religião e sua relação com o desrespeito à alteridade no espaço escolar. Partindo do conceito de Lévinas sobre alteridade, buscar-se-á analisar a relação conflituosa existente entre alunos adeptos de religiões de matriz africana e alunos que professam outra religião, buscando assim refletir para sobre o papel do professor nesses casos. Discussões como estas se fazem necessárias, pois, buscam meios para amenizar esses conflitos; para isso, fundamenta-se em pensadores que abordam a importância da não banalização do outro e da valorização das religiões de matriz africana, compreendendo que as mesmas fazem parte da realidade dos alunos e que, por muito tempo, foram inviabilizadas, demonizadas e, ainda hoje, passam por um processo de não aceitação por parte da sociedade, neste caso no meio escolar. Parte deste artigo foi apresentado durante o I Colóquio Internacional Bullying Submerso: Religião e Ełnicidade na Escola, promovido pelo Programa de pós-Graduação em Ciências da Religião da Pontifícia Universidade Católica de Goiás, em outubro de 2015, e é fruto de pesquisas realizadas ${ }^{2}$ no doutorado e de vivências enquanto professora de $1^{\circ}$ e $2^{\circ}$ fase da rede estadual da mesma cidade, e como umbandista Omó Ifá e abiã de orisá.

Palavras-chave: Religião, Educação, Diversidade, Alteridade.

\section{Education, diversity and respect for cultural identity ABSTRACT}

This proposal aims to discuss the social role of religion and its relationship with disrespect for otherness in the school space. Starting from Lévinas' concept of alterity, we will seek to analyze the conflictual relationship between students adhering to religions of African origin and students who profess another religion, thus seeking to reflect on the role of the teacher in these cases. Discussions like these are necessary, as they seek ways to alleviate these conflicts; for this, it is based on thinkers who approach the importance of not trivializing the other and valuing religions of African origin, understanding that they are part of the students' reality and that, for a long time, they were unfeasible, demonized and today go through a process of non-acceptance by society, in this case in the school environment. This article was presented during the 1st International Submerged Bullying Colloquium: Religion and Ethnicity at School Promoted by the Postgraduate Program in Religious Sciences at the Pontifical Catholic University of Goiás, in October 2015, and it is the result of research carried out at the doctorate and experiences as a teacher, from the 1st and 2nd phase of the state school network in the same city, and being Umbandista Omó Ifá and Abiã de Orisá.

Keywords: History teaching; Whiteness; Racism; Sexism; Mandatory Curricular Internships. Religion, Education, Diversity, Alterity.

\section{Submetido em: 27 de abr. de 2021 | Aceito em: 15 de jun. de 2021}

\footnotetext{
1 Professora Convidada da Universidade Federal do Tocantins (Campus de Arraias). Coordenadora Setorial da ANCTUR, Curso de Especialização Profissionalizante de Turismo e Patrimônio Cultural e Natural pela UFT. Professora da Pontifícia Universidade Católica de Goiás (PUC-Goiás), Curso de Letras. Diretora fundadora da Tekohá Pesquisas Patrimoniais e Arqueológicas. Quilombola Abiã de Orisá Omo Ifá, Licenciada em História (2004), Pós-graduada em Gestão do Patrimônio Cultural, Mestre em Gestão do Patrimônio Cultural, área de concentração Arqueologia, Doutora em Ciências da Religião, cursa Estágio Pós-Doutoral em História, área de pesquisas Cultura e Identidades dos falantes lorubá e da etnia lorubá. Atualmente compõe a rede de arqueólogos negros NEGRAARCHEO, NEAAD (UEG. Universidade estadual de Goiás), é Coordenadora do GT África e africanidades da ANPHU-regional Goiás, Pesquisadora fundadora da RELFET - Rede latino caribenha de pesquisadores sobre Feminismos de terreiros. E-mail: rosinegra@icloud.com

2 Essa pesquisa não recebeu financiamento, porém, parte dela foi realizada durante os estudos de doutorado (bolsista da CAPES 2014 a 2017).
} 


\title{
Introdução
}

\begin{abstract}
"Quanto mais se estudam as religiões melhor se compreende que elas do mesmo modo que as ferramentas e as linguagens estão inscritas no aparelho do pensamento simbólico. Por mais diversas que elas sejam respondem sempre a esta vocação dupla e solidaria para além das coisas, atingir um sentimento que the dê a plenitude das quais elas mesmas parecem privadas e arrancar cada ser humano do seu isolamento enraizando-o em uma comunidade que o conforte e ultrapasse". 3
\end{abstract}

O principal intuito deste ensaio é dialogar com a relação entre o papel social da religião e o desrespeito a alteridades do outro, partindo do conceito de Lévinas sobre alteridades e da relação conflituosa existente entre algumas religiões, gerada pelo fundamentalismo pregado por alguns religiosos que discriminam os adeptos das religiões de matriz africana, em especial no contexto escolar.

\section{Religião, alteridade e identidade}

A religião exerce para os que a nela creem uma ordenação da realidade, servindo de referencial contra o terror da anomia. Junto a esta função nomizadora, Berger acrescenta outras importantes funções exercidas pela religião na sociedade, dentre elas a de ordenado social. Há nela uma capacidade única de "situar os fenômenos humanos em um quadro cósmico de referência" dando a quem as pratica a sensação de alívio e um certo conforto. O autor afirma ainda que a religião pode ser entendida como um dos sistemas de símbolos fundamentais dos seres humanos ${ }^{4}$. Por sua vez Jung via a religião justamente como uma forma de ligar o consciente a fatores inconscientes importantes. Toda essa experiência religiosa foi sendo cristalizada, transformando-se em uma instituição imutável, que, via de regra, não significa uma petrificação sem vida, pois, pode representar uma experiência religiosa particular para inúmeras pessoas durante séculos, sem que haja a necessidade de serem modificadas em algumas religiões ${ }^{5}$.

Percebemos a religião como uma atitude do espírito humano, atitude que, de acordo com o emprego originário do termo "religio", poderíamos qualificar a modo de uma consideração e observação cuidadosas de certos fatores

\footnotetext{
3 Vernant apud Berger, 1985, pág. 6.

4 Berger, 1985.

5 Jung, 1978.
} 
dinâmicos concebidos como "potências" ou potencializados de nossa existência a exemplo dos espíritos, demônios, deuses, Orixás, Egúns, entidades, leis, ideias, ideais, ou qualquer outra denominação dada pelo homem a tais seres. Dentro de seu mundo próprio a experiência ter-Ihe-ia mostrado suficientemente poderosos, "perigosos" ou mesmo úteis, para merecerem respeitosa consideração, ou suficientemente grandes, belos e racionais, para serem piedosamente adorados e amados ${ }^{6}$.

A historia da humanidade é marcada por grandes catástrofes, guerras, pestes, fome, e em todas elas, de certa forma, para alguns grupos se pode perceber a presença de um "Deus", mas não estamos falando apenas do Deus monoteísta dos cristãos, judeus e muçulmanos, assinalado por todos os que nele creem como onipotente, mas em algo maior, em uma força cósmica mágica e incompreensível por sua magnitude e que gera um ordenamento ou até um desordenamento no planeta. Esse ser sagrado 7 é reverenciado, temido, desejado pelos indivíduos desde os primórdios; a exemplo de gravuras rupestres deixadas em sítios arqueológicos desde o período paleolítico. Essa relação é vivida por cada grupo de acordo com sua cosmovisão, e é perceptível que para alguns grupos esse sagrado está presente em tudo e que para outros está em outro plano, outro mundo. Então, quando se fala do sagrado se pensa onde ele se manifesta, e ao pensar nisto pensamos na sacralização do mundo através desses espaços, dessas manifestações. Quando esse sagrado se manifesta há a revelação de uma realidade absoluta. É a manifestação do sagrado que funda ontologicamente o mundo, revelando assim um espaço sagrado permitindo que o indivíduo obtenha um "ponto fixo", possibilitando o viver real daquela crença. Aí aparecem as teofanias e sinais, como por exemplo uma igreja, um terreiro, um templo, uma mesquita. Para um homem religioso esse lugar (igreja, templo, mesquita, terreiro, etc.) se torna um espaço diferente da rua onde ela se encontra, pois é o espaço

\footnotetext{
6 Jung, 1978, pág.10.

7Segundo Ribeiro (2020, pag 69) Para o negro africano, o visível constitui manifestação do invisível: Para além das aparências encontra-se a realidade, o sentido, o ser que através das aparências se manifesta. Sob toda manifestação viva reside uma força vital: "de Deus a um grão de areia, o universo africano é sem costura" (Erny, 1968, p.19). (...) Para o africano o sagrado permeia de tal modo todos os setores da vida africana, que se torna impossível realizar uma distinção formal entre sagrado e secular, entre o espiritual e o material nas atividades do cotidiano. In O Sagrado na Concepção lorubá (AFRICA OCIDENTAL)
} 
onde se manifesta o seu Deus. É uma espécie de portal entre os dois mundos, é a prova da presentificação de sua fé. Mas este homem religioso está inserido em um contexto que nem sempre é favorável ao que ele acredita, e por vezes ao se expressar ele entra em conflito com outros indivíduos. Esse outro individuo que pratica outra fé por vezes se contrapõe. Assim, nascem os conflitos por aversão, aversão ao outro, ao que ele representa, ao que ele acredita8.

Essa aversão por vezes chega às vias da violência, o que nos leva ao conceito de Lévinas sobre respeito à alteridade do outro. A alteridade, para ele, é a relação do "eu", enquanto ser humano, com o outro ser humano, que por vezes não se encaixa na relação do humano com o divino. Ou seja, o problema é a relação com divindades diferentes ou com o homem/mulher que prega outras divindades, pois, não reconhecemos essas divindades como tais, e assim rejeita-se as divindades e quem nelas acredita. Mais que rejeitar, algumas pessoas sentem às vezes, a necessidade de "eliminá-la", pois elas são vistas como uma ameaça às suas convicções. Nesse sentido, devemos nos perguntar o que é mais difícil aceitar: - "Outro" enquanto ser humano diferente e ao mesmo tempo igual a nós mesmos ou o outro religioso que prega e vivencia sua fé de forma diferente da nossa? Será que esse sentimento de rejeição está ligado ao medo de ver aflorar em nós uma visão religiosa que consideramos antiga (quase arcaica) que é subjacente em muitos cristãos e que podemos definir, simplificando, como visão pagã? Ou com ambas as coisas? Se é com ambas, o que nos parece mais forte: a dificuldade de aceitar a pessoa ou a sua religião?? Partindo destes questionamentos, seria possível escrever não apenas uma tese, mas várias, então nos ateremos a relacionar as indagações com os autores já citados e alguns exemplos de vivências. O primeiro ponto a se pensar quando se fala de respeito ao outro é à identidade ou às identidades de cada indivíduo. Digo identidades porque Hall10, em sua análise da evolução do conceito de identidade, mapeia as mudanças de sentido ocasionadas por algo que ele denomina de crise originada pela ação conjunta de um duplo deslocamento: a descentralização dos indivíduos tanto do seu lugar no mundo social e cultural quanto de si mesmos.

\footnotetext{
8 Berger, 1985.

9 Lévinas, 2000.

10 Hall, 1998, pag. 19.
} 
Simoni, R. O. C. S., Educação, diversidade e respeito à identidade cultural. ODEERE, v. 6, n. 01 , jan./jun., p. 163-182, 2021. https://doi.org/10.22481/odeere.v6i01.8522

Enquanto Hall assinala o período em que vivemos como de descentramento do sujeito, Rolnik 11, por sua vez, chama-o de período de identidades móveis. Para a autora, subjetividade e cultura são indissociáveis. $\bigcirc$ sujeito pós-moderno vive um tempo de identidades móveis, não está mais preso ao seu espaço geográfico, pois, a comunicação em rede traz consigo o contato com outras culturas e muitas possibilidades de identificação, ou de não identificação. As identidades e os papéis não são mais estáveis ou fixos, embora mantenham um perfil cultural e subjetivo afetado pelo ambiente. No coletivo este processo é mais visível, em se tratando de grupos marginalizados pelo contexto social, como é o caso de indígenas, africanos e afrodescendentes em suas diásporas. Esses grupos, e seus descendentes que, por muitos anos, foram considerados "coisas", ou seja, não humanos, buscaram e buscam o reconhecimento dentro da sociedade, não apenas o respeito. Devemos lembrar que há, na constituição do ser social, uma implicação de outras temporalidades e paisagens sociais. No conjunto de relações e representações sociais, o corpo é ao mesmo tempo lugar social e linguagem cultural e, sendo assim, permite trocas sociais e simbólicas. Tornar-se humano nesse contexto então é tornar-se indivíduos, é tornar-se individuais sob a direção dos padrões culturais, sistemas de significados criados historicamente em termos dos quais dá-se a forma, a ordem, o objeto e a direção as vidas ${ }^{12}$. Esses padrões culturais e identitários perpassam pela vivência religiosa, e permeiam as relações intra e extra-pessoais dos indivíduos, que por vezes se veem marginalizados por suas escolhas, em alguns casos também por suas origens, a exemplo dos afrodescendentes e praticantes de religiões de matriz africana. Os mesmos são vistos por alguns grupos como pagãos e em alguns casos ainda não são vistos como humanos, em virtude de padrões culturais e sociais oriundos do período da escravatura que ainda povoam a mente e influenciam nas posturas de algumas pessoas.

Na cosmovisão de algumas culturas africanas, dentre elas as lorubanas, todo o mundo é obra dos Deuses e é consagrado. Deus está em tudo, em todos. Nesse sentido a religião é parte fundamental de sua identidade, não existe separação entre ser e estar, somos porque estamos e vice-versa. Os deuses existem

\footnotetext{
11 Rolnik 1997, pág. 20-23.

12 Geertz, 1989, pág. 37.
} 
porque nós existimos, os deuses são presença e completude em tudo e todos. Essa cosmovisão ainda é vivenciada pelos afrodescendentes e adeptos das religiões de matriz africana, o que aumenta em torno dela uma atmosfera de rejeição por parte de alguns cristãos, em especial entre os convertidos às religiões pentecostais.

\section{Religiōes Afro-Brasileiras}

Segundo Faustino 13, a história da filosofia tem mostrado que estar na presença do outro implica um paradoxo. O Outro pode ser a um só tempo uma promessa boa, mas também uma ameaça. Ele pode despertar tanto o sentimento de desprezo quanto respeito, temor ou reverência. A grande questão é: qual dos dois sentimentos é mais passível de acontecer? Segundo Lévinas ${ }^{14}$, a questão do desrespeito à alteridade, revela-se, neste contexto, como um problema central que marca as relações sociais e o pensamento filosófico na contemporaneidade.

É cada vez mais comum e perceptível, nos diferentes espaços de convivência humana, uma crescente atitude de naturalização das formas de violência e da banalização do outro. A banalização do outro, segundo Miranda, é um sintoma que caracteriza a própria condição humana de nosso tempo. Essa postura, por vezes radical, se faz presente nos variados modos de fundamentalismos (religioso, político, cultural) que reafirmam uma postura de intolerância frente ao diferente, alimentada por um sentimento de superioridade perante o outro. Em contrapartida a essa postura, no cenário nacional, ressoam as reivindicações, por parte de diferentes grupos sociais, pela ampliação dos direitos humanos aos excluídos da história, a exemplo dos negros e indígenas. Esses grupos subalternizados tiveram por séculos sua cultura massacrada, e até a atualidade são obrigados a lutar pelo direito de ser. O desrespeito é contínuo e o principal alvo dos ataques são as cerimônias religiosas que por vezes são demonizadas por parte de alguns grupos cristãos.

É preciso ressaltar que a religião é uma forma de conservar a identidade, principalmente em um contexto de opressão, a exemplo dos africanos trazidos ao Brasil no período escravocrata. Esta busca por suas origens, e com ela a

\footnotetext{
13 Faustino, 2011.

14 Lévinas, 1997.
} 
Simoni, R. O. C. S., Educação, diversidade e respeito à identidade cultural. ODEERE, v. 6, n. 01 , jan./jun., p. 163-182, 2021 . https://doi.org/10.22481/odeere.v6i01.8522

preservação de sua identidade, fez com que os grupos africanos trazidos para esse continente, ao serem obrigados a se converter às religiões europeias, incorporassem a ela alguns elementos de suas religiões de origem, o que deu origem às religiões afro-brasileiras, como Umbanda, Candomblé, Catimbó, Jurema, Macumba, Tambor de Mina, Quimbanda, dentre outras. Essas religiões, também são conhecidas por pesquisadores da área como sincréticas e populares; porém o termo sincretismo vem sendo criticado por trazer a ilusão de uma fusão entre as religiões de matriz africana e o catolicismo. Alguns pesquisadores africanos como Munanga ${ }^{15}$ utilizam o termo pluralismo religioso: o autor acredita que esta definição contempla de maneira mais assertiva as diversas religiões que nasceram deste contato, nascidas em um contexto de opressão. As religiões de matriz africana carregam em seu contexto histórico marcas que as "diminuem" perante as outras. Neste sentido é possível perceber que há, no meio científico, um preconceito (uma espécie de senso comum intelectualizado, se assim optarmos por designá-lo) que desqualifica as expressões religiosas dos pobres e, por efeito da sobreposição do preconceito racial e cultural ao socioeconômico, dos negros. Ao refletir sobre aspectos históricos da religião negra, Luz'16 afirma que, longe de ser "ópio do povo", a religião negra é ponto básico, é fonte de afirmação dos valores civilizatórios negros e núcleo de resistência às variadas formas de aspirações neocolonialistas"17.

Então, se por um lado o povo de santo que constrói e reconstrói a religiosidade afro-brasileira desconhece os diálogos cômicos, por outro conhece e reconhece bem as gargalhadas dos Exus e Pombagiras da Umbanda. Quando se compreende a importância e o sentido de Exu no complexo cultural jeje-nagô, não é difícil pensá-lo como princípio dinâmico e nele compreender o que faz da Umbanda uma religião de raiz banto que agrega em seus rituais várias tradições religiosas de forma até harmoniosa. A Umbanda é uma religião que se ressignifica de acordo com seus pais e mães de santo (zeladores de terreiros), para atender o contexto, e seus adeptos demonstram assim um dos seus principais aspectos, a flexibilidade, a capacidade de dialogar com várias tradições religiosas, e a

\footnotetext{
15 Munanga, 2020.

16 LUz, 1983, p. 28.

17 Simoni, 2015.
} 
abertura para com os elementos que compõem o individuo pós-moderno. Esta bricolagem é um processo destacado como resposta religiosa que deu e dá origem ao pluralismo religioso das atuais manifestações de nossas religiões populares ${ }^{18}$.

Para Prandi, as religiões afro-brasileiras compõem um diversificado conjunto de credos, alguns de caráter local, outros já revestidos da característica de religião universal, que podem ser encontrados por todo o Brasil, e até mesmo em outros países, especialmente Argentina, Uruguai e Cuba. Mas trata-se também de um grupo minoritário no universo das religiões no Brasil 19. Reconstruir o processo histórico dessas religiões não é fácil, por serem originárias de segmentos marginalizados, e pelo fato de que elas têm como base a oralidade. A comunidade religiosa afrobrasileira, também conhecida como comunidade de terreiro Santo e de Asé, acarreta e fomenta a ideia de um "corpo grupal" oriundo das vivências coletivas que estão na base dessas religiões, forte o suficiente para dar proteção contra as adversidades e a hostilidade que sempre as perseguiu. A liturgia não deixa, assim, de exprimir uma prática política bastante clara, respaldando o grupo de possíveis "ataques"20. Na nossa concepção, as chamadas religiões afro-brasileiras podem ser pensadas como ressignificações das religiões africanas, tiveram suas origens no período escravocrata e, por isso, foram por anos praticadas e revestidas sob a luz dos santos católicos. O contexto social no qual nasceram, associado ao fato de seus praticantes serem considerados a priori como não "humanos" e, depois, como "primitivos", fazem com que essas religiões sejam vistas como pagãs e por vezes serem associadas a cultos satânicos. Me faço valer agora da concepção de Munanga sobre o conceito de sincretismo nas religiões de matriz africana, que de certa forma se contrapõe ao de alguns autores, pensamento com o qual comungamos e que vai ao encontro do que escrevemos acima:

Tudo isso que foi chamado sincretismo religioso pelos estudiosos das religiões africanas no Brasil. Sem dúvida, os sangues se misturaram, os deuses se tocaram e as cercas das identidades vacilaram, mas tem de ficar claro que não se trata de síntese no sentido de uma nova religião nascida dos contatos entre religiões de matriz africana e religiões cristãs. Trata-se de um pluralismo religioso caracterizado pelas

18Parker, 1996, p.34,

19Prandi, 2007 apud Simoni 2014, p. 47

20Sodré, 1999, p. 167-170 
trocas simbólicas e convivência pacífica num mesmo espaço social e geográfico. Como disse o Babalorixá Balbino de Apó Afonjá em Salvador, o Candomblé e o catolicismo são como a água e o óleo que, misturados na mesma bacia, ficam ali tranquilamente, mas em camadas separadas. Nada de síntese no sentido de A mais B igual C $(A+B=C)$; nada de caldeirão, mas simplesmente uma justaposição na mesma bacia. Assim, os Ibeji se aproximaram dos santos Cosme e Damião; Oxalá de Jesus ou Nosso Senhor do Bonfim; Yemanjá de Nossa Senhora da Conceição; Xangô de São Pedro; Oxossi de São Jorge; Obaluaé de São Lázaro, entre outros. ${ }^{21}$

Por essas premissas, as religiões de matriz africana foram e ainda são perseguidas por diversos seguimentos cristãos. Então, é preciso pensar em qual o real motivo dessa perseguição, dessa intolerância que circunda as religiões de matriz africana. Como respeitar um outro que, historicamente falando, nunca foi visto como um ser igual a mim? As religiões afrodescendentes, dentre elas a Umbanda, são fruto das religiões trazidas pelos africanos no período escravocrata, e estes aqui chegaram na condição de "mercadorias" vivas, que no máximo, para alguns, eram/chegavam a ser criaturas pagãs, e por isso havia a necessidade de convertê-los ao cristianismo. Como, depois de quase trezentos anos de escravização esses descendentes podem ser vistos como o Outro, como iguais? Para serem vistos como o Outro eles precisam ser vistos como seres humanos, mas por algumas pessoas isso ainda não é possível. Em suma, neste contexto, esse desrespeito à diversidade religiosa do outro não se encaixa ao conceito de alteridade de Lévinas ${ }^{22}$, porque para que isso aconteça, primeiro, os adeptos das religiões africanas precisam ser vistos como seres humanos iguais nas suas diferenças, e, segundo, precisam ser respeitados por essas diferenças, e assim a sua alteridade seria respeitada. A partir destas premissas históricas, devemos nos perguntar qual é o papel da educação na perpetuação desses pensamentos e comportamentos no que tange ao preconceito racial e perseguição que acarreta as religiões de matriz africana. E, ainda, como as escolas podem contribuir para essas desconstruções. Para compreender esse processo devemos iniciar com o conceito de intolerância religiosa, e a partir daí ressignificá-lo na prática escolar.

\footnotetext{
21 MUNANGA, 2020 pag. 10.

22 Lévinas, 1997.
} 


\section{Intolerância religiosa e o papel da escola nesse processo}

A palavra tolerância vem do termo tolerar. Este termo é usado quando estamos nos referindo a pessoas que ocupam posição superior ${ }^{23}$, significa permitir que pessoas que ocupam posição inferior possam ter a liberdade de cultuar seus deuses. Quem tolera não aceita o outro, não respeita, simplesmente permite uma coisa, ou um culto. Porém o que os excluídos, os discriminados podem tolerar da parte de pessoas que querem ditar a outrem as regras, comportamento e crenças? O que os pobres, miseráveis e explorados podem tolerar da parte de pessoas ricas e burguesas; os desmandos, humilhações? Citamos mais uma vez os pensamentos de Munanga ${ }^{24}$, que considera as palavras tolerar e não-tolerar impróprias, por acreditar que ninguém luta, trabalha e constrói para ser tolerado pelo outro, mas para ser, no mínimo, respeitado e tratado igualmente no que concerne aos direitos humanos fundamentais, entre os quais se incluem as liberdades de crenças, cultos e religião25. O que as religiões de matriz africana sofrem hoje, no Brasil, não é a intolerância em si, é uma discriminação racial que visa sua eliminação total do universo religioso brasileiro que é por definição plural.

A intolerância religiosa, no seu sentido literal, faz referência à falta de respeito em reconhecer a crença religiosa do outro. As crenças que cada indivíduo leva consigo são vistas como demarcadoras sociais e culturais, e a grande diversidade que existe no Brasil, e a etnicidade da qual esta nação foi gerada, fortalece e multiplica os casos de intolerância religiosa contra as religiões afrodescendentes. Muitas atrocidades já ocorreram em nome da religião, já que os "crentes" em determinada religião não toleravam outras crenças, e alguns acreditam que, se algumas crenças não existissem, a paz voltaria a reinar. Mas é impossivel falar de intolerância e falta de respeito para com o outro sem falar de ética e moralidade no espaço escolar.

A ética e a moralidade existem em todas as religiões. Entretanto, a perseguição religiosa determinada pela intolerância aos diferentes, é algo inadmissível. Cristianismo, Hinduísmo, Islamismo, Budismo, Judaísmo, Espiritismo,

\footnotetext{
23 Munanga, 2020.

24 Munanga, 2020

25Munanga, 2020, pág. 12.
} 
Simoni, R. O. C. S., Educação, diversidade e respeito à identidade cultural. ODEERE, v. 6, n. 01, jan./jun., p. 163-182, 2021. https://doi.org/10.22481/odeere.v6i01.8522

Espiritualismo, Candomblecismo, Umbandismo são apenas alguns exemplos de religiões do Brasil, cada qual com seus dogmas, ritos e símbolos. Essa diversidade religiosa é, sem dúvida, uma das mais marcantes características da humanidade. Estimativas indicam que há mais de duas mil religiões e mais de dez mil seitas no mundo atualmente. E no Brasil, são mais de cinco grupos principais. Tamanha multiplicidade de crenças tornou ainda mais complexa a relação entre os povos. Assim como a diversidade étnica, a diversidade religiosa acabou resultando em intolerância nas mãos do homem. Neste sentido, voltamos mais uma vez nas palavras citadas acima e no seu significado ético e moral.

Segundo Ribeiro, ${ }^{26}$ as palavras ética e moral dizem respeito à princípios e regras de conduta. A moral tem referência à dignidade, justiça e generosidade. A ética abrange a dimensão moral, o respeito pela dignidade alheia e pela justiça. Ética é princípio, moral é o aspecto de conduta específico. Ética é permanente e a moral é temporal. Ética é universal e a moral é cultural. Ética é regra e a moral é conduta da regra. Ética é teoria, moral é prática. Por isso, se aplicarmos esses conceitos na conduta religiosa, buscando compreender qual das duas palavras é mais importante para estabelecer uma sociedade moral, cada religião escolheria um preceito, dependendo de sua visão do que vem a ser moral. Já o conceito de moralidade depende do grupo que o interpreta e vivencia. Então, devemos ressaltar que a moral não deve ser fundamentada em uma única religião, pois cada religião vê a moral de uma forma. A religiosidade não é indispensável para haver a moralidade, pois ela vai além da conduta religiosa.

$\mathrm{Na}$ verdade, uma pessoa pode viver com moralidade sem ser adepto de religião nenhuma, pois a moralidade determina a minha postura perante o outro, e isso pode ser percebido, por exemplo, quando não respeitamos aos sinais de trânsito, quando procuramos levar vantagem em tudo. Quando temos esse tipo de conduta perante os outros conferimos a todos os meus semelhantes os direitos de fazer o mesmo comigo ${ }^{27}$. Nesse contexto podemos nos perguntar onde entra Deus em tudo isto. Ora, ele exerce muitas funções de acordo com os grupos: há os que acham que Deus é necessário para explicar o que é certo e errado, porque acreditam que nós não seríamos capazes disso, ou para punir quem se desvie do

\footnotetext{
26 Ribeiro 2006, apud Martines, 2019.

27 RIBEIRO, 2006 apud MARTINES, 2019.
} 
bom caminho. Mas, se hoje a conduta ética dos ateus ou indiferentes não tem nada a dever à dos religiosos e sobretudo à dos intolerantes, é porque essa tese moderna de uma ética humana tem valor e validade, depende do contexto do grupo e do que este grupo deseja.

Sabemos que as religiões estão cheias de princípios éticos, entretanto nem todos os sistemas éticos têm uma base religiosa. Vários cientistas, humanistas, ateus, podem acabar desenvolvendo sistemas éticos muito eficientes e consistentes, demonstrando que não somente a religião pode fornecer material para que uma pessoa viva dentro da moralidade. Martines apud Ribeiro, ao analisar os pensamentos de Santo Agostinho sobre ética, moralidade e religião, afirma que: podemos ou não acreditar em Deus, mas eu ser ou não ético deixa de estar subordinado ao medo de um Deus assustador. Uns serão éticos, mesmo não acreditando nele. Por sua vez, outros cultuarão um Deus de justiça e amor, mais que dá repressão e castigo. A crença em Deus ganha, em vez de perder, quando o indivíduo corta o vínculo preferencial com o inferno e o medo, o que de certa forma o deixa "livre" de qualquer remorso e culpa 28 .

Partindo dessa premissa podemos dizer que, na verdade, a intolerância é construída visando evitar a todo o custo a vivência dessa alteridade radical, numa tentativa de gerir o conflito e de administrar o risco de ser alterado por esse outro, ou seja matamos por medo de morrer, não nosso corpo, mas nossas crenças e com elas nossas certezas. Esse preconceito para com o outro por vezes nos cega e esquecemos que o mesmo preconceito é nada mais que a nossa noção formada sobre o outro e a intolerância é a negação do outro como tal. "As atitudes de intolerância que realizamos ou que podem ser notadas em nosso cotidiano são, nesse contexto, compreendidas como práticas de defesa contra nossa fragilidade diante do outro."29. Esta postura se agrava quando esse Outro é aquele quem fomos "educados" historicamente a negá-lo até como Outro, pois, na história ele foi silenciado pela condição "social" de subalterno, e por vezes não humano. Somos frutos dessa história, onde os grupos subalternos negros e indígenas não eram respeitados e vistos nem como indivíduos. Então como conceber sua cultura e religião como algo a ser respeitado? É preciso reescrever os conceitos de

\footnotetext{
28 RIBEIRO, 2006 apud MARTINES, 2019.

29 AQUINO, 1998, p. 131.
} 
Simoni, R. O. C. S., Educação, diversidade e respeito à identidade cultural. ODEERE, v. 6, n. 01, jan./jun., p. 163-182, 2021. https://doi.org/10.22481/odeere.v6i01.8522

alteridade ética e moral para que os mesmos abarquem todos os grupos, mesmos os que chegaram em terras brasileiras em condições subalternizadas, já que a diversidade religiosa e cultural vivenciada em terras brasileiras se deve a esses grupos. O sentido da palavra tolerância deve nestes casos levar em conta a articulação equilibrada entre identidade e diversidade, não podendo um substituir o Outro mas devendo um se igualar ao Outro. A tolerância somente pode florescer na diversidade, porém, se não houver "pontos de contato" entre as crenças, o diálogo estará inviabilizado e, assim, some a possibilidade de compreensão e respeito mútuo.

É possível perceber que, no caso das religiões de matriz africana, a intolerância religiosa vai além da religião. E está ligada a um contexto étnicohistórico onde o Outro em questão, por muitos séculos, foi visto como um "animal irracional", sem alma, que servia a deuses pagãos e que precisava ser salvo por esse "Deus único" e cristão para qual trabalhavam os fiéis. Fiéis que, em nome desse Deus, perseguem e até destroem terreiros pautando-se no discurso de que só o seu Deus pode salvar essas almas perdidas. Há uma dicotomia entre o discurso e os feitos desses cristãos que, por vezes, viram notícias por tamanha violência. Eles estão buscando almas para salvar e buscam justamente naqueles (adeptos das religiões de origem africana) que para eles representam o mal, contra o qual eles lutam. Se eles já são parte desse mal o que eles querem salvar? É possível que essa insistência venha do desejo de demonstrar poder. Neste sentido, o fundamentalismo religioso aparece como algo que consolida e ao mesmo tempo divide a religião.

O que dizer quando este fundamentalismo religioso, esta falta de ética alcança o meio escolar? A escola se transforma em um lugar excludente e reafirmado de pré-conceitos que fomentam posturas que não condizem com o papel social da educação, o de ordenador de conceitos, de fomentadora do respeito para a diversidade cultural do país.

Em seu livro Pedagogia da Autonomia, Freire30 afirma que: "não existe docência sem discência [...] e que ensinar exige reflexão crítica sobre a prática". Nesta obra ele aborda a necessidade de se fazer uma releitura da postura do

30 FREIRE, 1996, pág. 23. 
professor enquanto formador de opiniões. Será que ele está mesmo formando estas opiniões ou está reproduzindo conceitos e pré-conceitos estabelecidos por uma história escrita por uma minoria, que insiste em excluir a maioria que construiv está mesma história? É possível perceber esta afirmação no cotidiano das escolas na postura quase que previsível de alunos sobre determinados assuntos, em especial no que tange às relações étnico raciais e sobre o papel do negro no contexto histórico. Precisamos nos perguntar o que sabemos sobre os Africanos, que tanto contribuíram para formação de nossa nação, e, enquanto professores, o que temos ensinado aos nossos alunos. Qual o papel do professor neste processo de ensino aprendizagem, como ensinar algo que ainda desconhecemos?

A esse respeito Barbosa apud Mairena ${ }^{31}$ afirma que: "A finalidade de nossa escola é ensinar a repensar o pensamento, a "des-saber" o sabido e a duvidar de sua própria dúvida; esta é a única maneira de começar a acreditar em alguma coisa"32. Partindo deste contexto, podemos afirmar que, para que a educação cumpra seu papel, será necessário construir novos horizontes, o que significa transformar o discurso em atitudes concretas. É preciso que os profissionais da educação busquem conhecer a realidade que os cerca, mapeando os conflitos em busca de soluções para que a educação se torne o agente transformador, e consiga realmente favorecer a diversidade cultural e religiosa.

\section{Considerações Finais}

No Brasil especificamente tem-se constatado que a quebra da hegemonia católica, que durante séculos se deu, vem sendo acompanhada pela emergência de um quadro religioso plural que se manifesta no país, sobretudo ao redor das religiões pentecostais que vem apresentando expressiva diversidade, com destaque para o crescimento do número de adeptos. Este pluralismo religioso, que observamos não só no Brasil, como também em outros países, no entanto não tem conduzido à democracia e à tolerância entre as religiões ${ }^{33}$. Pelo contrário, a presença dele tem provocado manifestações de intolerância, pois a diversidade

\footnotetext{
31 Mairena, 1974 apud Barbosa, 2000.

32 Mairena, 1974,

33 Oro e Steil, 1997.
} 
Simoni, R. O. C. S., Educação, diversidade e respeito à identidade cultural. ODEERE, v. 6, n. 01 , jan./jun., p. 163-182, 2021. https://doi.org/10.22481/odeere.v6i01.8522

que tem se evidenciado no âmbito das religiões tem promovido um processo de pluralização das identidades. E elas, ao invés de interagirem, acabam lutando entre si pela hegemonia através de processos conflitivos que muitas vezes têm culminado no estigma e na violência para com grupos e pessoas ${ }^{34}$. Esse processo, associado a banalização do Outro, é mais perceptível na relação das religiões de matriz africana com alguns segmentos religiosos pentecostais. Essa relação conflituosa por vezes acaba em violência explicita, manchete em alguns meios de comunicação, a exemplo de crianças impedidas de entrar em sala de aula portando seus símbolos sagrados. Segundo Oliveira35, é preciso lembrar que esse modelo de ciência moderna, expresso sobretudo nos cânones positivistaevolucionistas, assentou-se na ideia de uma razão que, acreditando, poder retratar a realidade com acurada objetividade, levaria consequentemente o(a) cientista ao encontro de uma verdade, absoluta e universal. Essa perspectiva de ciência promoveu, entre outros fatores, fundamentos que respaldavam a destruição do Outro, sendo esse Outro o diferente, o marginalizado, o subalterno, o não-europeu, em especial o negro e ameríndio. Este paradigma de certa forma se relaciona diretamente com o problema da tolerância/intolerância, porque serve de fundamento para a descoberta de verdades universais, certezas absolutas, coloca-nos frente a frente com a problemática da exclusão social e cultural visível nos diversos casos de bullying na escola, e em outros espaços.

Esta possibilidade de exclusão e de intolerância, citada por Clodoaldo Cardoso36 em "Tolerância e seus Limites: um olhar latino-americano sobre a diversidade e desigualdade" apud Oliveira, é sublinhada quando ele afirma que, no campo da identidade, a própria busca da tolerância na modernidade, significando algo puro, homogêneo, concebido em termos de valor universal, conduzirá a um ideário tal que negará a pluralidade humana, relegando o diferente ao lugar do submisso, do anormal, do estranho, do não-existente ou do manipulável ${ }^{37}$. Essa razão alicerçada historicamente em algumas ideias fundamentalistas, é a responsável pelas posturas que revelam a negação do outro e o desrespeito a sua alteridade. Este outro, por vezes em formação quando se

\footnotetext{
34 Burity, 1997, 1999; Giumbelli, 2003; Oliveira, 2006.

35 Oliveira, 2008.

36 Cardoso, 2003 apud Oliveira, 2008.

${ }^{37}$ Cardoso, 2003, apud Oliveira, 2008 pag. 128.
} 
trata de crianças vitimas de bullying, se vê impossibilitado de ser e de estar, pois vê nessas atitudes excludentes uma negação de sua existência enquanto ser igual nas suas diferenças.

Ainda segundo Oliveira, ${ }^{38}$ os sentidos de tolerância na modernidade, predominantes nos dicionários das línguas latinas, revelam a ideologia da cultura europeia em seu projeto de universalidade e homogeneidade pela dominação das outras culturas. Essa tolerância do conquistador, argumenta Cardoso, não expressa o reconhecimento da alteridade e sim expressa uma atitude necessária de suportar a presença do Outro para preservar uma ordem universal, pois com isso o civilizado estaria impedindo o comportamento violento dos povos indígenas ${ }^{39}$. Em suma, afirma a autora, essa perspectiva de tolerância deu sustentáculo ao extermínio dos povos indígenas e à escravização de negros africanos por portugueses e espanhóis à medida que, por serem considerados como inferiores aos humanos, uma subespécie da raça, só restava à eliminação e a escravidão caso não se submetessem àqueles tidos como humanos de fato. $E$ esta suposta superioridade europeia é visível na postura de alguns indivíduos que compõem os diversos segmentos religiosos cristãos nascidos na Europa. Alguns indivíduos carregam essa mesma "certeza" de uma missão fictícia de semear o "bem" em nome de seu Deus cristão e salvar assim os infiéis, os subalternos, os pagãos, levando a sua verdade religiosa, que para eles é a única, e assim é para eles justificável que adeptos de religiões de matriz africana sejam perseguidos ou invisibilizados em nome dessa suposta tolerância que visa a paz e a aceitação dos outros inferiores em todos os aspectos. Infelizmente, posturas como estas são comuns em algumas escolas gerando um ciclo vicioso e pré-conceituoso onde a ordem ainda é colonizar o outro, nesse caso os alunos de segmentos religiosos afro.

\section{Referências Bibliográficas}

ALVES, M. A. Da fenomenologia à responsabilidade ética: uma breve análise desde o pensamento de Lévinas.

\footnotetext{
$3^{8} \mid \mathrm{BI}$

${ }^{39}$ Cardoso, 2003 apud Oliveira, 2008.
} 
ANDRADE, Claudionor Corrêa de. Dicionário teológico e suplemento biográfico dos grandes teólogos e pensadores. 15 ed. Rio de Janeiro: CPAD, 2006.

AQUINO, Júlio Groppa. Diferenças e Preconceitos na Escola. Alternativas Teóricas e Práticas. São Paulo: Summus, 1998.

ARISTÓTELES. Ética a Nicômaco. São Paulo: Martin Claret, 2003.

BARBOSA, Joaquim Gonçalves: Autrews cidadãos a sala de aula na perspectiva Multireferencial São Carlos Ed. UFScar,2000.

BERGER, Peter Ludwuing. O dossel sagrado: elementos para uma teoria sociologica da religião, Editora Paulinas São Paulo 1985.

BERGER, Peter. A dessecularização do mundo: uma visão global. Religião e Sociedade, v. 21, n. 1, 2001, pp. 9-23.

BíBLIA. Português. Bíblia de Estudo Almeida. Traduzido por: João Ferreira de Almeida. Barueri: Sociedade Bíblica do Brasil, 2006.

BONFATTI, Paulo. A expressão popular do sagrado. Uma análise psicoantropológica da Igreja Universal do Reino de Deus. São Paulo: Paulinas, 2000.

BRANDÃO, Carlos Rodrigues. Os deuses do povo. São Paulo: Brasiliense, 1980.

BURITY, Joanildo Albuquerque. Identidade e Política no Campo Religioso. Recife, Editora Universitária 1997.

BURITY, Joanildo Albuquerque. Globalização e Identidade: desafios do multiculturalismo, Recife, I Conferência Latino-Americana e Caribenha de Ciências Sociais 1999.

CARDOSO, Clodoaldo (2003), Tolerância e Seus Limites: um olhar latino-americano sobre diversidade e desigualdade, São Paulo, Editora UNESP.

FREIRE, Paulo. Pedagogia da autonomia: saberes necessários à prática educativa, São Paulo: Paz e Terra, 1996.

HALL, Stuart. A Identidade Cultural na Pós-Modernidade, Rio Janeiro, DP\&A editora 
2001.

HOBBES, Thomas. Leviatã. Traduzido por: João Paulo Monteiro e Maria Beatriz Nizza da Silva. São Paulo: Abril Cultural, 1985.

LÉVINAS, E. Descobrindo a existência com Husserl e Heidegger. (1949). Trad. Fernanda Oliveira. Lisboa: Instituto Piaget, 1999.

LÉVINAS, E. Totalidade e infinito: Ensaio sobre a exterioridade. Trad. José Pinto Ribeiro. Lisboa: Ed. 70, 2000.

LÉVINAS, E. Humanismo do outro homem. Trad. Pergentino S. Pivatto. Petrópolis: Vozes, 1993.

LÉVINAS, E. Ética e infinito. Trad. João Gama. Lisboa: Ed. 70, 1988.

LÉVINAS, E. Entre Nós: Ensaio sobre a alteridade. (1991). Trad. Pergentino S. Pivatto. Petrópolis: Vozes, 1997.

LOPES, Jose da Silva. Ensaios de intolerância religiosa, artigo, Maceió julho 2011.

MARTINES, PAULO. O ato moral Segundo Tómas de Aquino. Artigo disponível em: https://www.scielo.br/pdf/trans/v42nspe/0101-3173-trans-42-spe-0249.pdf acessado em: Março 2021.

MIRANDA, José Valdinei Albuquerque.Ética da alteridade e educação [manuscrito] / José Valdinei Albuquerque Miranda; orientadora: Nadja Mara Amilibia Hermann. - Porto Alegre, 2008. 188 f. tese de doutorado.

MUNANGA, Kabengele, NILMA, Lino Gomes. Para Entender o Negro no Brasil Hoje. São Paulo: Ed. Global, 2004.

MUNANGA, Kabengele. As religiões de Matriz africana e intolerância religiosa artigo publicado em Crítica e Sociedade: revista de cultura política, Uberlândia, v. 10, n. $1,2020$.

NORA, Pierre. Entre a memória e a história: a problemática dos lugares. Revista Projeto de História. São Paulo, PUC/SP, n. 10, 1993. 
OLIVEIRA, Anderson José Machado de. Os santos pretos carmelitas: culto dos santos, catequese e devoção negra no Brasil colonial. Tese (Doutorado) Universidade Federal Fluminense, Niterói, 2002.

OLIVEIRA, Manuel de Jesus. Família Almeida: a construção de um patrimônio imaterial. Dissertação (Gestão do Patrimônio Cultural) - Universidade Católica de Goiás, Goiânia, 2005.

OLIVEIRA, Aurineia, Maria. Multiculturalismo, Pluralismo e Tolerância e/ou Intolerância Religiosa: a perspectiva dos espíritas kardecistas em Pernambuco em relação aos adeptos das religiões afro-brasileiros.

ORO, Ari. Pedro \& STEIL, Carlos Alberto (Orgs.) 1997 Globalização e Religião, 2a ed. Petrópolis, Vozes.

ORTIZ, Renato. A morte branca do feiticeiro negro. Petrópolis: Ed. Vozes, 1978.

ORTIZ, Renato. Cultura Brasileira e Identidade Nacional. São Paulo: Ed. Brasiliense, 1986.

PESSOA, Jadir de Morais. Saberes em festa: gestos de ensinar e aprender na cultura popular. Goiânia: Ed. Kelps, 2005.

REDDING, Amalhene Baesso; LEITE, Maria Isabel. O Lugar Da Infância Nos Museus. In: MUSAS - Revista Brasileira de Museus e Museologia. p.32-41. n. 3, 2007, Rio de Janeiro, Instituto do Patrimônio Histórico e Artístico Nacional.

RIBEIRO, Romilda lyakemi. O Sagrado - concepção lorubá (Africa Ocidental) artigo publicado em Diálogos entre Psicologia e Espiritualidade e Meio Ambiente: Sagrado em perspectiva Organizadora: Marlise A. Bassami Editora Puc-São Paulo 2020. Acessado em: janeiro 2021

RICOUER, Paul. Tempo e Narrativa. Tomo I. Campinas: Papirus, 1994

RICOEUR, Paul 1995. Em Torno ao Político, São Paulo, Loyola 1995.

ROLNIK, Suely. Toxicômanos de identidade. In: LINS, Daniel (org.). Cultura e subjetividade: saberes e modos. Campinas: Papirus, 1997 (2. Ed.). 
ROLNIK, Suely. Uma Viagem Insólita à subjetividade - fronteiras com a ética e a cultura. In: LINS, Daniel S. (org.). Cultura e Subjetividade: Saberes Nômades. Campinas: Papirus, 1997.

SILVA, Vagner Gonçalves da (org.). Intolerância religiosa. Impactos do Neopentecostalismo no campo religioso afro-brasileiro. São Paulo: Editora da Universidade de São Paulo, 2007. p. 328.

SIMONI, Rosinalda C. Da Silva. Educar para diversidade uma questão de respeito a identidade, artigo apresentado em: I Colóquio Internacional Bullyng Submerso: Religião e Etnicidade na Escola Promovido pelo Programa de Pós-Graduação em Ciências da Religião da Pontifícia Universidade Católica Goiânia 2015.

TEIXEIRA, Faustino. Sociologia da religião. Enfoques teóricos. Petrópolis: Vozes, 2003.

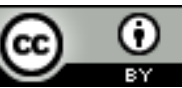

This work is licensed under a Licence Creative Commons Attribution 4.0 International License.

Este trabalho está licenciado com uma Licença Creative Commons - Atribuição 4.0 Internacional. 